\title{
DIFFERENCES BETWEEN THE ACTIVITIES OF MATURE GRANULOCYTES IN LEUKEMIC AND NORMAL BLOOD ${ }^{1}$
}

\author{
By A. I. BRAUDE,2 JOYCE FELTES, AND MARTIN BROOKS
}

(From the Department of Internal Medicine, University of Michigan, Ann Arbor, Mich.)

(Submitted for publication January 1, 1954; accepted March 22, 1954)

The abnormal appearance and number of granulocytes in the various leukemias suggest that phagocytosis by granulocytes in all stages of maturity might be so disturbed that leukemic patients might become more susceptible to bacterial infections than normal persons. Phagocytic activity among immature granulocytes is only slight but increases with maturity and becomes prominent among metamyelocytes and mature leukemic neutrophils (1-4). It has not been established, however, whether mature leukemic neutrophils are equal in phagocytic activity to normal mature neutrophils. Such a comparison has been attempted by Hirschberg (5) who concluded that the mature neutrophils in leukemic blood displayed less phagocytic activity than mature neutrophils in normal blood. Her results are open to question, however, because comparisons were made between phagocytic systems which were not uniform with respect to: 1) The number of phagocytes per unit volume ; 2) quantity of opsonin; and 3 ) character of suspending menstruum. She also neglected to take into account the possible effect of antileukemic treatment on the phagocytic properties of leukocytes.

In the present study, the activity of mature leukemic granulocytes was measured in two ways: 1 ) Suspensions of leukemic and suspensions of normal leukocytes, containing approximately equal numbers of mature granulocytes, were inoculated with opsonized type II pneumococcus and the phagocytic activity of leukemic granulocytes was compared with that of normal granulocytes. 2) Heparinized leukemic blood was divided into two portions and the buffy coat removed from one to lower the count of mature neutrophils to normal

1 This investigation was supported (in part) by a research grant from the National Cancer Institute of the National Institutes of Health, Public Health Service.

2 Present address: Department of Internal Medicine, Southwestern Medical School of the University of Texas, Dallas, Texas. levels; each portion was inoculated with pathogenic staphylococci and the number of culturable staphylococci were counted before and after six hours' incubation.

The simultaneous performance of these two tests on specimens from a given patient provided information not only on the action of single mature granulocytes in a standardized menstruum, but also on the collective action of leukemic leukocytes in their own blood. Observations were also made : 1) On the effect of antileukemic therapy on phagocytosis by neutrophils; and 2) on the incidence of bacterial infection in the patients whose leukocytes were examined.

\section{METHODS AND MATERIALS}

1. Clinical material. Patients were studied at the University Hospital or the Simpson Memorial Institute of the University of Michigan. The diagnosis of leukemia was established in each case by staff members of the Simpson Institute through laboratory examination of peripheral blood and bone marrow and clinical examination of the patient. The number of cases of each type of leukemia and the treatments are listed in the protocol. Roentgen irradiation was administered at the University Hospital under the supervision of Dr. Isadore Lampe.

Freshly drawn samples of venous blood obtained from these patients were divided into two portions. One portion was used to provide leukocytes for the test with opsonized pneumococci and one portion was inoculated with pathogenic staphylococci as described below.

2. Measurement of leukocyte activity in a standard phagocytic system. Leukocytes from patients with small buffy layers and from normal persons were separated from fresh venous blood (containing heparin $0.5 \mathrm{mg}$. per ml. as anticoagulant) by permitting the erythrocytes to sediment at $37^{\circ} \mathrm{C}$. for 30 minutes in a glass tube tilted at 60 degrees; then the supernatant plasma was removed with a warm sterile pipette. Supernatant plasma obtained in this way usually contained at least as many leukocytes per cu. mm. as existed in the whole blood, but almost no erythrocytes. Sometimes it was necessary to centrifuge the supernate or the blood itself at 500 r.p.m for $\mathbf{5}$ minutes to remove the erythrocytes. The leukocytes were sedimented only slightly at this speed. At first, only siliconized glassware was used, but later it was 
TABLE I

Antibacterial action of leukemic whole blood and of suspensions of leukemic leukocytes from patients with chronic granulocytic leukemia *

CHRONIC GRAMULOCYTIC LEUAEMIA

\begin{tabular}{|c|c|c|c|c|c|c|c|c|c|c|c|c|c|c|c|}
\hline \multirow{3}{*}{$\begin{array}{c}\text { NAME } \\
\text { AGE } \\
\text { OURATION }\end{array}$} & \multirow{3}{*}{ oATE } & \multirow{3}{*}{$\begin{array}{r}480 \\
\times 1000 \\
\end{array}$} & \multicolumn{7}{|c|}{$\begin{array}{l}\text { PERIPHCRAL BLO00 } \\
\text { OIFFEREMTIAL } \\
\end{array}$} & \multicolumn{5}{|c|}{ 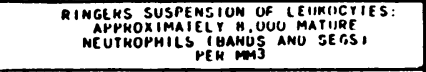 } & \multirow{3}{*}{ tacatment } \\
\hline & & & \multirow[t]{2}{*}{$\mathbf{s}$} & \multirow[t]{2}{*}{8} & \multirow[t]{2}{*}{1} & \multirow[t]{2}{*}{ o } & \multirow[t]{2}{*}{ 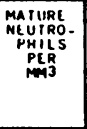 } & \multicolumn{2}{|c|}{ 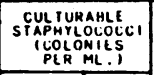 } & \multicolumn{3}{|c|}{ 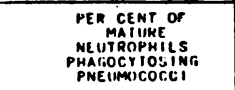 } & \multicolumn{2}{|c|}{ 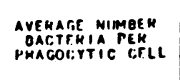 } & \\
\hline & & & & & & & & BEF ORE & $\begin{array}{l}\text { AF IER } \\
\text { AOURS } \\
\text { HOUR }\end{array}$ & $5 / 8$ & PATIENT & CONTROL & PATIENT & CONIROL & \\
\hline \multirow{3}{*}{$\begin{array}{l}R . F . \\
65 \\
5 \rightarrow 0 .\end{array}$} & $3 / 24 / 53$ & 476. & 13 & - & 73 & 5 & 105,000 & 16.800 & 106 & $90 / 10$ & 11 & 100 & 7.0 & 10.5 & 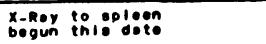 \\
\hline & 3/27/53 & 364. & 30 & 14 & 54 & 2 & 160.000 & 18.000 & 3.600 & $55 / 45$ & 25 & 100 & 3.2 & 8.1 & $\begin{array}{l}\text { 3rd dey of } x-R o y \\
\text { to opioon }\end{array}$ \\
\hline & $4 / 2 / 53$ & 148. & 52 & 33 & 8 & 2 & 125,000 & 18.600 & 848 & $48 / 52$ & 78 & 100 & 2.0 & 14.5 & 1 weox oftor $x-$ ked \\
\hline 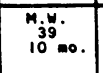 & $3 / 19 / 53$ & 8. & 50 & 0 & 0 & 50 & 4.000 & 22,000 & 4,400 & $100 / 0$ & 100 & 100 & 16.0 & 16.0 & 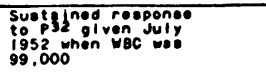 \\
\hline \multirow{4}{*}{ 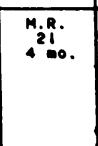 } & $4 / 24 / 53$ & 410. & 18 & 39 & 39 & 4 & 240.000 & 4.800 & 1.560 & $60 / 40$ & 48 & 100 & 8.9 & 3.8 & Mone \\
\hline & $4 / 29 / 53$ & 370. & 21 & 14 & 55 & 10 & 130.000 & \begin{tabular}{|l|}
20.000 \\
\end{tabular} & 694 & $80 / 20$ & 4 & 90 & 10.0 & 9.0 & Urethone oterted $4 / 28 / 53$ \\
\hline & \begin{tabular}{ll|}
$5 / 5 / 53$ \\
\end{tabular} & 379. & 35 & 29 & 33 & 3 & 255.000 & 18.000 & 648 & $55 / 45$ & 18 & 46 & 4.5 & 4.7 & I weok of urethane \\
\hline & $5 / 11 / 53$ & 338. & 45 & 23 & 30 & 2 & 230.000 & 9.600 & 32 & $20 / 80$ & 11 & 100 & 0.7 & 9.5 & $\begin{array}{l}\text { Urethane "topped } \\
\text { preceding day }\end{array}$ \\
\hline \multirow{2}{*}{ E.J. } & $12 / 15 / 52$ & 430.5 & 29 & 33 & 26 & 12 & 275.000 & 21.000 & 1.018 & & 38 & 100 & 3.3 & 9.0 & \\
\hline & $12 / 23 / 52$ & \begin{tabular}{|l|l}
222. \\
\end{tabular} & 28 & 33 & 31 & 8 & 140.000 & & & & 74 & 100 & 13.5 & 17.7 & p32 on $12 / 17 / 52$ \\
\hline 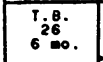 & $1 / 12 / 53$ & 85. & 51 & 6 & 33 & 10 & 49.000 & & & 67/33 & 66 & 67 & 9.8 & 23.3 & 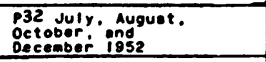 \\
\hline & $2 / 9 / 53$ & 143. & 48 & 14 & 28 & 10 & 92.000 & 18.000 & 688 & $84 / 16$ & 26 & 100 & 9.6 & 10.5 & p32 this dete \\
\hline & $4 / 10 / 53$ & 62. & 54 & 26 & 10 & 10 & 50.000 & 18.800 & 1.640 & $88 / 12$ & 60 & 90 & 5.0 & 10.7 & $\begin{array}{l}\text { Potel body } \\
\text { irred bodition } \\
\text { 3/30/53 to } 4 / 10 / 53\end{array}$ \\
\hline A.E. & $2 / 20 / 53$ & 19. & 76 & of & 10 & $\mid 14$ & 15.000 & 20.6001 & 12.000 & $100 \%$ & 21 & 86 & 1.3 & 20.1 & No recent treatment \\
\hline & $3 / 6 / 53$ & 11. & 72 & 2 & 0 & 26 & 9.000 & 22,000 & 6.200 & $95 / 5$ & 95 & 95 & 16.2 & 16.6 & 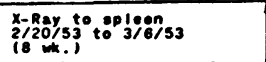 \\
\hline M.p. & $1 / 12 / 53$ & 730. & 16 & 28 & 55 & I & \begin{tabular}{|l|}
300.000 \\
\end{tabular} & 13.680 & 276 & $64 / 36$ & 15 & 100 & 19.5 & 25.0 & None \\
\hline $0^{55} \mathrm{mo}$. & $1 / 14 / 53$ & 800. & 18 & 34 & 65 & 3 & 400.000 & 19.600 & 588 & & 0 & 90 & 0.0 & 15.0 & \\
\hline H.P. & $3 / 31 / 53$ & 37. & $\cdot$ & 13 & 42 & 38 & 0.100 & 18.000 & 6.000 & 60/40 & 66 & 94 & 16.5 & 13.0 & 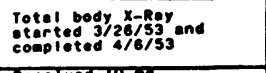 \\
\hline $\begin{array}{l}\mathrm{M}_{\mathrm{si}} \mathrm{s} . \\
3 \mathrm{yr} .\end{array}$ & $4 / 29 / 53$ & 340. & 28 & 6 & 71 & 3 & 115.000 & 10.800 & 360 & $40 / 80$ & 15 & 80 & 3.0 & 9.0 & 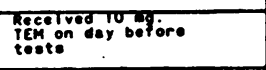 \\
\hline $\begin{array}{l}6.5 . \\
366 . \\
3 \mathrm{yr} .\end{array}$ & $3 / 20 / 53$ & 82 . & 45 & 18 & 23 & 14 & 51.000 & 20.160 & 940 & $90 / 10$ & so & 100 & 5.0 & 15.0 & 32 3/19/53 \\
\hline $\begin{array}{l}\text { E.s. } \\
\text { E. } \\
2 \mathrm{yr} . \\
\end{array}$ & $8 / 12 / 52$ & 23. & 58 & 17 & 15 & 20 & 14.900 & & & & $\infty 0$ & 03 & 6.6 & 10.3 & $P 321 / 14 / 52$ \\
\hline F.0. & $7 / 7 / 52$ & 39.7 & 38 & 52 & 1 & 9 & & & & $75 / 25$ & 69 & 96 & 11.1 & 12.4 & Mo rocont thorspy \\
\hline & $7 / 11 / 52$ & 25.1 & 35 & so & 4 & "1 & & & & 65/35 & 55 & 05 & 5.5 & 6.0 & 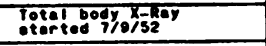 \\
\hline & $9 / 16 / 52$ & 140. & s & 0 & 95 & 0 & 7,000 & 18.360 & 182 & & & & & & 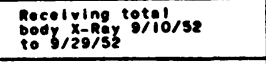 \\
\hline & $9 / 25 / 52$ & 151.3 & - & 3 & 91 & 0 & 13,600 & $28.000 \mid$ & 3.040 & & & & & & 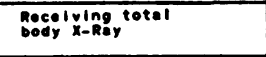 \\
\hline & $10 / 3 / 52$ & 187. & 1 & 3 & 96 & 0 & 7,500 & 28.000 & $5,980 \mid$ & & & & & & \\
\hline Hisi. & $7 / 28 / 52$ & 100. & 40 & 16 & 39 & 3 & & & & $70 / 30$ & 3 & 44 & 14.5 & 7.3 & 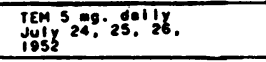 \\
\hline & $10 / 16 / 52$ & 72.5 & 46 & 16 & 32 & 6 & 45.000 & 25.800 & 7.800 & & & & & & \\
\hline 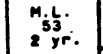 & $12 / 15 / 52$ & 174.5 & 36 & 31 & 37 & 6 & 110,000 & 21.600 & 0.400 & $50 / 50$ & 30 & 100 & 9.0 & 14.0 & 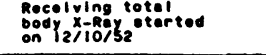 \\
\hline & $1 / 30 / 53$ & 174. & \begin{tabular}{|l|}
20 \\
\end{tabular}$-10$ & 28 & 35 & - & 102.000 & 22,000 & 0.000 & $40 / 60$ & 32 & .2 & 4.0 & 7.0 & 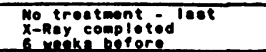 \\
\hline & $2 / 4 / 53$ & 209. & 57 & 23 & 20 & 10 & 120.000 & 18.000 & 6.600 & & & & & & \\
\hline & $3 / 17 / 53$ & 288.5 & 31 & 28 & 40 & 1 & 162.000 & 18,240 & 970 & $40 / 60$ & 40 & 100 & 4.0 & 23.0 & $\begin{array}{l}\text { X-Rey thorapy to } \\
\text { Rt humerug }\end{array}$ \\
\hline & $3 / 10 / 53$ & 220. & 22 & 22 & 58 & 0 & 97.000 & 17,000 & 2,600 & 50/50 & 15 & 02 & 3.0 & 4.2 & 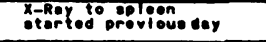 \\
\hline & $3 / 31 / 53$ & 10.5 & 45 & 32 & 16 & 7 & 12.700 & 19.000 & 8.400 & $80 / 10$ & 67 & 94 & 7.0 & 13.0 & 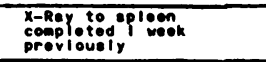 \\
\hline$J_{i 2 .} \cdot$ & $10 / 13 / 52$ & 107. & 34 & 31 & 30 & 5 & 130.000 & 10,800 & 80 & & & & & & $p 32$ 9/5/52 \\
\hline & $10 / 15 / 32$ & 183. & 32 & 16 & 52 & 0 & .1 .000 & 18.000 & 1.000 & & & & & & 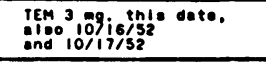 \\
\hline & $10 / 21 / 52$ & 83. & 47 & 28 & 24 & 3 & 65.000 & 24.600 & 600 & & & & & & \\
\hline$\frac{6}{3} \cdot 6.0$. & $12 / 4 / 52$ & 45.5 & 50 & 10 & 23 & 17 & 27,000 & 29.000 & 13,200 & & & & & & P32 12/3/32 \\
\hline 4.6. & $11 / 24 / 52$ & 114. & 24 & 18 & 38 & 20 & 46.000 & 24.240 & 6.600 & & & & & & None \\
\hline 42 & $12 / 2 / 52$ & 113.5 & 40 & 5 & 53 & 2 & 50.000 & 1.000 & 12 & & & & & & $\begin{array}{l}\text { Rocolving urothano } \\
\text { 3.g. delyy }\end{array}$ \\
\hline & $2 / 4 / 53$ & 129. & 21 & 18 & 37 & $24 \mid$ & 52.000 & 18,000 & 1.568 & & & & & & Rocolving urothene \\
\hline$w_{33}^{H .}$ & $0 / 20 / 52$ & 282. & 31 & 17 & 42 & 10 & 140,000 & T8.480 & 806 & & & & & & None \\
\hline $13 \mathrm{mo.}$ & $10 / 27 / 52$ & 24.6 & 40 & 22 & 14 & 24 & 16.000 & 13.200 & 7.000 & & & & & & 132 on $8 / 21 / 32$ \\
\hline 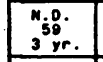 & $3 / 11 / 53$ & oo. & 40 & 3 & 18 & 39 & 33,000 & 19.200 & 5.000 & & & & & & 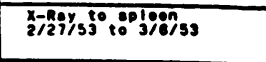 \\
\hline Eis. & $5 / 29 / 52$ & 03.4 & 7 & 51 & 42 & 0 & 40.000 & 16,300 & 16,750 & & & & & & 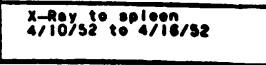 \\
\hline
\end{tabular}

* Whole bloods were inoculated with pathogenic staphylococci, and leukocyte suspensions with opsonized type 2 pneumococci ( $S=$ segmented neutrophils, $B=$ band neutrophils, $I=$ immature neutrophils, $O=$ leukocytes other than neutrophils; $S / B=$ ratio of segmented to band forms.) 
found that comparable results were obtained with clean glassware which had not been treated with silicone. Leukocytes from patients with high counts were easily separated by pipetting the thick buffy coat from heparinized venous blood. The plasma suspensions of leukocytes were centrifuged at 1,000 r.p.m. for 5 minutes. The supernatant plasma was then removed and replaced by Ringer's solution containing $0.5 \mathrm{mg}$. heparin per $\mathrm{ml}$. The Ringer-heparin solution was added in amounts necessary to give a final count of approximately 8,000 mature neutrophils per cu. $\mathrm{mm}$. No attempt was made to remove the immature neutrophils also present in the suspension. Mature neutrophils were defined as band forms and segmented forms. Immature neutrophils were defined as metamyelocytes, myelocytes, progranulocytes, and myeloblasts. All cells were identified according to the criteria reported by the committee for clarification of the nomenclature of cells (6).

A type II pneumococcus, highly virulent for mice and containing a large capsule rendering it resistant to phagocytosis in the absence of specific opsonin in vitro, was subcultured on rabbit blood-agar plates. At the time of each test, freshly grown cultures of the pneumococcus were removed from the surface of the plate with a platinum wire and the bacteria suspended in Ringer's solution to give a density equal to that of the No. 1 tube of the MacFarland nephelometer. The pneumococcal suspension was distributed in $0.1 \mathrm{ml}$. quantities among six glass test tubes measuring $15 \times 100$. Rabbit sera containing high titers of specific type II pneumococcal antibody were used to opsonize the pneumococcus by adding $0.02 \mathrm{ml}$. of antiserum to each of two tubes containing pneumococcal suspension. Pneumococci in two other tubes were similarly treated with antiserum diluted in Ringer's solution; those in the other two tubes with normal non-immune rabbit serum. The dilute antiserum was used to cover the possibility that diminished phagocytic activity of leukemic cells might not be apparent in the presence of excess antibody. The mixtures of serum and pneumococci were incubated in a water bath at $37^{\circ} \mathrm{C}$. for 30 minutes. Then $0.1 \mathrm{ml}$. of leukemic cells suspended in Ringer's was added to one of each of the three pairs of

TABLE II

Antibacterial action of leukemic whole blood and suspensions of leukemic leukocytes from patients with acute and subacute granulocytic leukemia*

ACUTE AND SUBACUTE GRANULOCYTIC LEUKEMIAS

\begin{tabular}{|c|c|c|c|c|c|c|c|c|c|c|c|c|c|c|c|}
\hline \multirow{4}{*}{$\begin{array}{c}\text { MAME } \\
\text { OURATIION } \\
\text { OURATI }\end{array}$} & \multirow{4}{*}{ DATE } & \multicolumn{8}{|c|}{ PERIPHERAL BLOOD } & \multicolumn{4}{|c|}{ 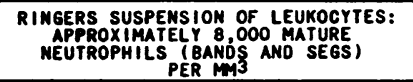 } & \multirow{4}{*}{$\begin{array}{c}\text { TYPE OF } \\
\text { GRANULOCYTIC } \\
\text { LEUKEMIA }\end{array}$} & \multirow{4}{*}{ TREATMENT } \\
\hline & & \multirow{3}{*}{$\begin{array}{l}\text { NBC } \\
\times 1000\end{array}$} & \multirow{3}{*}{\begin{tabular}{|l|}
011 \\
8 \\
\end{tabular}} & ffer & ent & & \multirow{3}{*}{ 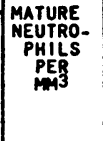 } & \multirow{2}{*}{\multicolumn{2}{|c|}{$\begin{array}{l}\text { CULTURABLE } \\
\text { STAPHYOCOCOCI } \\
\text { PCOLONES } \\
\text { PER ML.) } \\
\end{array}$}} & \multirow{2}{*}{\multicolumn{2}{|c|}{$\begin{array}{l}\text { PER CENT OF } \\
\text { MATURE } \\
\text { MEUTROPHILS } \\
\text { PHACOCYTOS SING } \\
\text { PMEUHOCOCGI }\end{array}$}} & \multirow{2}{*}{\multicolumn{2}{|c|}{$\begin{array}{l}\text { AYERAGE MUMBER } \\
\text { BACIERIA PER } \\
\text { PHAGOCYTIC CELL }\end{array}$}} & & \\
\hline & & & & \multirow[t]{2}{*}{$B$} & \multirow[t]{2}{*}{1} & \multirow[t]{2}{*}{0} & & & & & & & & & \\
\hline & & & & & & & & BEFORE & $\begin{array}{l}\text { AFTER } \\
6 \\
\text { HOURS }\end{array}$ & PATIENT & CONTROL & PATIENT & CONTROL & & \\
\hline $\begin{array}{l}0 . W . \\
52.0 .\end{array}$ & $7 / 5 / 52$ & 6.1 & 11 & 0 & 65 & 24 & & & & 75 & 82 & 6.7 & 11.1 & SA;SL & None \\
\hline 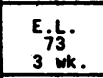 & $3 / 6 / 53$ & 15.6 & 39 & 1 & 1 & 59 & 6,000 & 22,200 & 4,800 & 92 & 95 & 11.5 & 16.6 & SA; SL & None \\
\hline E.T. & $3 / 5 / 53$ & 3.96 & 59 & 9 & 11 & 30 & 2,400 & 20,000 & 150 & 51 & 60 & 3.8 & 3.0 & SA;SL & 7 \\
\hline $\begin{array}{l}1.8 . \\
22 \\
4.0 .\end{array}$ & $11 / 15 / 52$ & 5.6 & 16 & 3 & 81 & 0 & & & & 77 & 82 & 4.5 & 7.0 & SA;SL & None \\
\hline $\begin{array}{l}6.5 . \\
59.9 .\end{array}$ & $3 / 24 / 53$ & 227. & 20 & 2 & 62 & 16 & & & & 68 & 100 & 4.1 & 10.5 & Acute & None \\
\hline $\begin{array}{l}\text { R.y. } \\
\text { is } \\
\text { ge. }\end{array}$ & $3 / 19 / 53$ & 32.5 & 22 & 6 & 70 & 2 & & & & 98 & 82 & 9.9 & 4.2 & Acute & cortisone \\
\hline 2 is. & $3 / 31 / 53$ & 4.5 & 18 & 3 & 38 & 41 & 900 & 20,400 & 13,200 & 100 & 100 & 40.0 & 10.0 & Acute & None \\
\hline \multirow{4}{*}{$\begin{array}{c}6, M . \\
25 \\
4=0 .\end{array}$} & $8 / 15 / 52$ & 11. & 15 & 4 & 74 & 7 & & & & 58 & 44 & 5.3 & 6.0 & Acute & $\begin{array}{l}\text { Acth } 25 \mathrm{mg} . \\
\text { for } 2 \text { days }\end{array}$ \\
\hline & $.10 / 13 / 52$ & \begin{tabular}{|l|}
49.75 \\
\end{tabular} & ii & 6 & 73 & 10 & 8.500 & 18,000 & 4,800 & & & & & & Mone \\
\hline & $10 / 15 / 52$ & 127. & 6 & 2 & 90 & 2 & 10,000 & 29,000 & 6,000 & & & & & & None \\
\hline & $10 / 21 / 52$ & 60.5 & 6 & 4 & 88 & 2 & 6.000 & 24,880 & 14,400 & & & & & & Mone \\
\hline $\begin{array}{l}\text { Fin. } \\
\text { it. } \\
6 \text { mo. }\end{array}$ & $10 / 23 / 52$ & 17. & 28 & 36 & 19 & 17 & 11,500 & 24,000 & 2,400 & & & & & SA;SL & \\
\hline $\begin{array}{l}\text { P.c. } \\
7_{\text {sio. }}\end{array}$ & & 26.5 . & 16 & 14 & 4 & 66 & $-7,900$ & 28,000 & 17,600 & 97 & 88 & 15.0 & 0.0 & sA & \\
\hline Fic. & $1 / 26 / 53$ & 145. & 2 & 1 & 91 & 6 & 4,600 & 24,000 & 17,600 & & & & & & $\begin{array}{l}\text { Cortisone } \\
75 \mathrm{gg} .-6 \mathrm{H}\end{array}$ \\
\hline
\end{tabular}

* (S.A. = Subacute, SL = Subleukemic ; abbreviations of cells same as Table I; L = Lymphocytes $)$. 
TABLE III

Antibacterial action of leukemic whole blood and suspensions of leukocytes from patients with chronic lymphocytic leukemia *

CHRONIC LYMPHOCYTIC LEUKEMI

\begin{tabular}{|c|c|c|c|c|c|c|c|c|c|c|c|c|c|c|}
\hline \multirow{3}{*}{$\begin{array}{l}\text { NAME } \\
\text { AGE } \\
\text { OURATION }\end{array}$} & \multirow{3}{*}{ DATE } & \multicolumn{8}{|c|}{ PERIPHERAL BLOOO } & \multicolumn{4}{|c|}{ 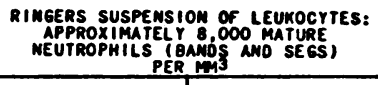 } & \multirow{3}{*}{ TREATMENT } \\
\hline & & \multirow[t]{2}{*}{$x_{x}^{\text {Mac }}$} & \multirow[t]{2}{*}{ s } & a & \multirow[t]{2}{*}{ I } & \multirow[t]{2}{*}{$\mathbf{L}$} & \multirow[t]{2}{*}{$\begin{array}{c}\text { MATURE } \\
\text { MEUTRO- } \\
\text { PHILS } \\
\text { PER } \\
\text { PET } \\
\end{array}$} & \multicolumn{2}{|c|}{$\begin{array}{c}\text { CUL TURABLE } \\
\text { STAPHYLOCCCCI } \\
\text { (COLONIES } \\
\text { PER } \\
\text { MLI) }\end{array}$} & \multicolumn{2}{|c|}{$\begin{array}{l}\text { PER CEMT OF } \\
\text { MATURE } \\
\text { MEUTROPHIIS } \\
\text { PHAGOCYTOSING } \\
\text { PWEUHOCOCCI }\end{array}$} & \multicolumn{2}{|c|}{$\begin{array}{l}\text { AYERAGE MUMBER } \\
\text { BACIER IA PER } \\
\text { PHAGOCYTIC CELL }\end{array}$} & \\
\hline & & & & o] & & & & BEFORE & $\begin{array}{l}\text { Af TER } \\
6 \\
\text { HOURS } \\
\end{array}$ & PATIENT & CONTROL & PATIENT & CONTROL & \\
\hline $\begin{array}{l}\text { W. } \\
48 . \\
1 \text { mo. }\end{array}$ & $11 / 21 / 52$ & 128. & 1 & 0 & 0 & 99 & 1,280 & 26,400 & 13,200 & 85 & 46 & 5.1 & 12.2 & Mone \\
\hline J.P. & $4 / 24 / 53$ & 352.5 & $<1$ & $\mathbf{0}$ & 0 & $99+$ & $<3.500$ & 23,400 & 16.800 & 100 & 100 & 20 & 12 & $x$ : Ray to spleen $4 / 23 / 53$ to $5 / 5 / 53$ \\
\hline $\begin{array}{l}\text { Mic. } \\
7 \text { yid. } \\
7 \text { yr. }\end{array}$ & $12 / 2 / 52$ & 24. & 23 & 0 & 1 & 76 & & & & 100 & 100 & 10.9 & 7.2 & $\begin{array}{l}\text { Receiving } x \text { : Ray to nodes } 11 / 3 / 52 \\
\text { to } 12 / 13 \% 52\end{array}$ \\
\hline $\begin{array}{l}\text { J.4. } \\
677^{2} \\
2 \mathrm{yr} .\end{array}$ & $\begin{array}{r}3 / 5 / 53 \\
4 / 17 / 53 \\
\end{array}$ & $\begin{array}{l}400 . \\
280 .\end{array}$ & $\begin{array}{l}1 \\
3 \\
\end{array}$ & $\begin{array}{l}0 \\
0\end{array}$ & $\begin{array}{l}0 \\
0\end{array}$ & $\begin{array}{l}99 \\
97\end{array}$ & $\begin{array}{l}4.000 \\
8.400 \\
\end{array}$ & $\begin{array}{l}23,400 \\
18,600\end{array}$ & $\begin{array}{r}14.400 \\
6.600 \\
\end{array}$ & 76 & 22 & 9.5 & 8.6 & $\begin{array}{l}x: R a y, \text { to regional node } 2 / 23 / 53 \\
\text { to } 3 / 5 / 53 \text { a } \\
6 \text { weeks after completion of } x: \text { Ray }\end{array}$ \\
\hline A.v. & $3 / 31 / 53$ & 51. & 9 & 0 & 0 & 91 & 4.590 & 17,000 & 9,600 & 88 & 94 & 17.6 & 13 & \\
\hline $\begin{array}{l}\text { Jim. } \\
21.0 .\end{array}$ & $3 / 3 / 53$ & 186. & 8 & 0 & o & 92 & 15,000 & 19.600 & 8,160 & 82 & 100 & 15 & 15 & $x$ : Ray to nodes $2 / 25 / 53$ to $3 / 9 / 53$ \\
\hline $\begin{array}{l}\text { A.R. } \\
23^{2} \\
2.5 r .\end{array}$ & $12 / 1 / 52$ & 8.7 & 41 & 0 & 0 & 59 & 3,600 & 25,600 & 2,640 & 100 & 100 & $>40$ & 15 & None within 6 months: \\
\hline $\begin{array}{l}J .0 . \\
2.98 .\end{array}$ & $4 / 21 / 53$ & 15.3 & 24 & 0 & 2 & 74 & 3,500 & 18,144 & 14,994 & & & & & 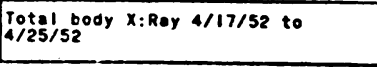 \\
\hline
\end{tabular}

* Abbreviations same as Tables I and II.

TABLE IV

Antibacterial action of leukemic whole blood and suspensions of leukocytes from patients with acute and subacuta lymphocytic leukemia *

ACUTE AMD SUBACUTE IYMPHOCYTIC AMO MONOCYTIC LEUKEMIA

\begin{tabular}{|c|c|c|c|c|c|c|c|c|c|c|c|c|c|c|c|c|}
\hline \multirow{3}{*}{$\begin{array}{l}\text { NAME } \\
\text { AGE } \\
\text { DURATION }\end{array}$} & \multirow{3}{*}{ DATE } & \multirow{3}{*}{$\begin{array}{r}\text { Y8C } \\
\times 1000\end{array}$} & \multicolumn{8}{|c|}{ PERIPHERAL BLOOOO } & \multicolumn{4}{|c|}{$\begin{array}{l}\text { RINGERS SUSPENSION OF LEUKOCYTES: } \\
\text { APPPOXIMATELY \&, OOO MATURE } \\
\text { MEUTROPHILS (BANOS ANO SEGS) } \\
\text { PER MMI }\end{array}$} & \multicolumn{2}{|c|}{$\begin{array}{l}\text { PM: Promonocytes } \\
\text { B: Blosts } \\
\text { L: Lymphocytes } \\
\text { I: Innumerable }\end{array}$} \\
\hline & & & \multirow[t]{2}{*}{ sB } & \multirow[t]{2}{*}{ M } & \multirow[t]{2}{*}{ PM } & \multirow[t]{2}{*}{ B } & \multirow[t]{2}{*}{$\mathbf{L}$} & \multirow[t]{2}{*}{$\begin{array}{l}\text { MATURE } \\
\text { NEUTRO- } \\
\text { PHILS } \\
\text { PER } \\
\text { min3 }\end{array}$} & \multicolumn{2}{|c|}{$\begin{array}{c}\text { CULTURABLE } \\
\text { STAPHYOCOCCI } \\
\text { (COLONIES } \\
\text { PER ML.) } \\
\end{array}$} & \multicolumn{2}{|c|}{$\begin{array}{l}\text { PER CENT OF } \\
\text { MATURE } \\
\text { NEUTROPHILS } \\
\text { PHAGOCYTOSING } \\
\text { PNEUMOCOCGI } \\
\end{array}$} & \multicolumn{2}{|c|}{$\begin{array}{l}\text { AVERAGE NUMBER } \\
\text { OACTERIAA PER } \\
\text { PHACOCYTIC CELL }\end{array}$} & \multirow{3}{*}{$\begin{array}{l}\text { TYPE OF } \\
\text { LEUKEMIA }\end{array}$} & \multirow[t]{2}{*}{ TREATMEA } \\
\hline & & & & & & & & & BEFORE & $\begin{array}{c}\text { Ar IER } \\
6 \\
\text { HOURS } \\
\end{array}$ & PATIENT & CONTROL & PATIENT & CONTROL & & \\
\hline \multirow[t]{3}{*}{$\begin{array}{l}\mathrm{H}_{3} \mathrm{~T} . \\
2 \text { mo. }\end{array}$} & $4 / 15 / 53$ & 120. & 0 & 0 & 50 & 43 & 7 & 0 & 18,000 & 21,600 & $\begin{array}{l}0 \\
\text { Promon. } \\
\text { active }\end{array}$ & 100 & I & 15 & & None \\
\hline & $4 / 17 / 53$ & 51. & 0 & 0 & 25 & 66 & 9 & 0 & 12,000 & 9,600 & $\begin{array}{l}0 \\
\text { Promon. } \\
\text { active }\end{array}$ & 100 & 1 & 12.5 & & \\
\hline & $4 / 29 / 53$ & 12. & 0 & 0 & 30 & 64 & 6 & & & & $\begin{array}{l}\text { O-promon. } \\
\text { active }\end{array}$ & 89 & I & 9. & & \\
\hline C.K. & $5 / 5 / 53$ & 1.2 & 2 & 0 & 0 & 30 & 69 & 24 & 368 & 2.400 & & & & & $\begin{array}{l}\text { Subacute } \\
\text { Subleukemic } \\
\text { Monocytic }\end{array}$ & None \\
\hline $\begin{array}{l}W .5 . \\
58 \\
2 W .\end{array}$ & $9 / 26 / 53$ & 5.35 & 17 & 13 & 10 & 38 & 22 & $\begin{array}{r}920 \\
+650 \\
\text { mono- } \\
\text { cytes } \\
\end{array}$ & 738 & 348 & & & & & $\begin{array}{l}\text { Acute } \\
\text { Subleukenic } \\
\text { Monocytic }\end{array}$ & None \\
\hline A. Gh & $4 / 10 / 53$ & 19. & 3 & 0 & 0 & 0 & 97 & 570 & 824 & 11,600 & 90 & 90 & 33 & 10.7 & $\begin{array}{l}\text { Subacute } \\
\text { Subleukenic } \\
\text { Lyaphocytic }\end{array}$ & None \\
\hline${ }_{80}^{\text {A. }}$. & $12 / 23 / 52$ & 2.1 & 8 & 0 & 0 & 0 & 92 & 168 & 1,368 & 3,600 & & & & & $\begin{array}{l}\text { Subacute } \\
\text { Subleukenic } \\
\text { Lymphocytic }\end{array}$ & None \\
\hline
\end{tabular}

tubes and $0.1 \mathrm{ml}$. of normal cell suspension to each of the corresponding three tubes. All tubes were sealed with paraffin and the mixtures of leukocytes and opsonized pneumococci were rotated in a machine at 6 r.p.m. for 15 minutes. The tubes were opened and a drop of the con- tents spread on a glass coverslip. The film was dried, stained with Wright's Stain, and mounted on a glass slide. Phagocytic activity was determined as follows:

Approximately 100 mature neutrophils were counted; the number which had ingested pneumococci were re- 
corded and subsequently referred to as "Per cent phagocytosis." The total number of intracellular pneumococci were also counted and the average number of pneumococci ingested were recorded for those cells which contained intracellular organisms. Results in Tables I, II, III, and IV are given for undiluted opsonin because the results with diluted opsonin were confirmatory.

3. Measurements of the antibacterial action of whole leukemic blood. The purpose of this experiment was to determine the capacity of whole leukemic blood inoculated with pathogenic staphylococci to lower the bacterial count after 6 hours incubation at $37^{\circ} \mathrm{C}$. Pathogenic staphylococci were selected as the test organism not only because they produced most bacterial infections in leukemic patients, but also because they multiplied rapidly in fresh plasma or in leukocyte-free whole blood incubated at $37^{\circ} \mathrm{C}$. Although this test has been regarded as a measure of bactericidal activity, it has been demonstrated that the decrease in number of bacterial colonies results from phagocytosis and intracellular clumping, rather than from killing of staphylococci (7). When leukemic or normal phagocytes are disrupted with distilled water or by raising the $\mathrm{pH}$ above 10 , the dispersed cocci grow separately instead of in clumps and the number of colonies increases greatly in the agar plates. The alkaline $\mathrm{pH}$ also breaks up the extracellular clumps of coagulase positive staphylococci which are present in plasma.

The strain of staphylococcus (B) used in all experi- ments had been isolated from human empyema fluid. It clotted human plasma, clumped instantly in fibrinogen solution, and on blood agar produced hemolysis and a golden yellow pigment. It was maintained in a smooth phase by frequent subculture on blood agar. For routine tests, the staphylococci were grown for 18 hours in tryptose phosphate broth and then resuspended in saline to give a density equal to that of the No. 1 tube of the MacFarland nephelometer. The suspension of staphylococci was then diluted in saline either to $10^{-6}$ or $10^{-3}$ depending on whether heavy or light inoculums were desired. Because of the large errors involved in reaching a given dilution by pipetting, numbers of bacteria were selected for inoculation that could be counted in agar plates without serial dilution.

Leukemic whole blood used in these experiments was part of that drawn to provide leukocytes for the standardized phagocytic system in Section 1 and permitted simultaneous performance of both procedures on aliquots from the same sample. The portion used for inoculation with staphylococci was divided into equal aliquots; the leukocyte count was lowered considerably in one of the aliquots by pipetting off the buffy coat. Two and one half $\mathrm{ml}$. of blood with buffy coat intact and $2.5 \mathrm{ml}$. of blood with buffy coat removed were each inoculated with $0.5 \mathrm{ml}$. of staphylococcal suspension and incubated for 6 hours at $37^{\circ} \mathrm{C}$. in tubes measuring $38 \times 180 \mathrm{~mm}$. The tubes were not agitated because it was found that agitation for a

TABLE V

Antibacterial action of leukemic whole blood measured by its ability to reduce the number of culturable staphylococci (coagulase positive) during 6 hours incubation: Effect of lowering to approximately normal the numbers of mature granulocytes by removing the leukemic buffy coat (Compare with Table $V A$ which gives results for normal blood)

\begin{tabular}{|c|c|c|c|c|c|c|}
\hline \multirow{3}{*}{ Patient } & \multirow{3}{*}{$\begin{array}{c}\text { MUMBER MATURE } \\
\text { GRANULOCYYES } \\
\text { (SEGS AND BANDS) } \\
\text { PER MM3 }\end{array}$} & \multirow{3}{*}{$\begin{array}{l}\text { BUFFY } \\
\text { COAT } \\
\text { REMOVED }\end{array}$} & \multicolumn{4}{|c|}{$\begin{array}{c}\text { STAPHYLOCOCCI CUL TURED BEFORE AND AFTER } 6 \text { HOURS } \\
\text { INCUBATION IN LEUKEMIC WHOLE BLOOD } \\
\text { (COLONIES PER ML.) }\end{array}$} \\
\hline & & & \multicolumn{2}{|c|}{ LARGE INOCULUM } & \multicolumn{2}{|c|}{ SMALL INOCULUM } \\
\hline & & & BEFORE & AFTER 6 HOURS & BEFORE & AF TER 6 HOURS \\
\hline $\begin{array}{l}R \text { R F } \\
3 / 24 / 53\end{array}$ & $\begin{array}{r}160,000 \\
7,000 \\
0\end{array}$ & $\begin{array}{l}\text { no } \\
\text { yes } \\
\text { Plasma }\end{array}$ & $\begin{array}{l}18,000 \\
22,000\end{array}$ & $\begin{array}{r}3,600 \\
26,000\end{array}$ & $\begin{array}{l}790 \\
712 \\
840\end{array}$ & $\begin{array}{r}810^{8} \\
9,600\end{array}$ \\
\hline $4 / 2 / 53$ & $\begin{array}{r}125,000 \\
9,000\end{array}$ & $\begin{array}{c}\text { no } \\
\text { yes } \\
\text { Plasma }\end{array}$ & $\begin{array}{l}18,600 \\
16,400 \\
20,000\end{array}$ & $\begin{array}{c}828 \\
16,800 \\
\text { Innumerable }\end{array}$ & $\begin{array}{r}1.170 \\
546\end{array}$ & $\begin{array}{r}10 \\
650\end{array}$ \\
\hline Ė/is/52 & $\begin{array}{r}275,000 \\
6,500\end{array}$ & $\begin{array}{c}\text { no } \\
\text { yes } \\
\text { Plasma } \\
\end{array}$ & $\begin{array}{l}21,000 \\
30,000 \\
\text { unable } \\
\end{array}$ & $\begin{aligned} 10,000 \\
32,400 \\
\text { to obtain }\end{aligned}$ & $\begin{array}{r}516 \\
1.058 \\
\text { cell-free } \\
\end{array}$ & $\begin{array}{r}10 \\
1,640 \\
\text { piasma }\end{array}$ \\
\hline li/24/52 & $\begin{array}{l}46,000 \\
10,500\end{array}$ & $\begin{array}{c}\text { no } \\
\text { yes } \\
\text { Plasma }\end{array}$ & $\begin{array}{l}24,240 \\
24,480\end{array}$ & $\begin{array}{r}6,600 \\
20,800\end{array}$ & $\begin{array}{l}1,376 \\
1,440 \\
\end{array}$ & $\begin{array}{r}112 \\
634 \\
18,000 \\
\end{array}$ \\
\hline$M_{3}^{M} / 17 / 53$ & $\begin{array}{r}162,000 \\
4,200\end{array}$ & $\begin{array}{c}\text { no } \\
\text { yes }\end{array}$ & $\begin{array}{l}18,240 \\
16,800\end{array}$ & $\begin{array}{r}970 \\
21,000\end{array}$ & $\begin{array}{r}620 \\
658 \\
1.024\end{array}$ & $\begin{array}{r}1.83 \\
16.306\end{array}$ \\
\hline $3 / 31 / 53$ & $\begin{array}{r}12,700 \\
4,000\end{array}$ & $\begin{array}{c}\text { no } \\
\text { yes } \\
\text { Plasma }\end{array}$ & $\begin{array}{l}19,800 \\
18,000\end{array}$ & $\begin{array}{r}8,400 \\
18,000\end{array}$ & $\begin{array}{r}920 \\
1,058 \\
1,018 \\
\end{array}$ & $\begin{array}{r}288 \\
1,158 \\
2,400 \\
\end{array}$ \\
\hline 2/20/53. & $\begin{array}{r}15,000 \\
5,700\end{array}$ & $\begin{array}{c}\text { no } \\
\text { yes } \\
\text { plasma }\end{array}$ & $\begin{array}{l}20,600 \\
20,800\end{array}$ & $\begin{array}{l}12,000 \\
19,700\end{array}$ & $\begin{array}{l}1,008 \\
1,188 \\
1,018\end{array}$ & $\begin{array}{r}330 \\
4,000 \\
20,000\end{array}$ \\
\hline$M_{1 / 12 / 53}^{P}$ & $\begin{array}{r}300,000 \\
26,000\end{array}$ & $\begin{array}{c}\text { no } \\
\text { yes } \\
\text { plasma }\end{array}$ & $\begin{array}{l}13,680 \\
29,400 \\
\text { unable }\end{array}$ & $\begin{array}{c}476 \\
20,400 \\
\text { to obtain }\end{array}$ & $\begin{array}{c}652 \\
\text { cell-free }\end{array}$ & $\begin{array}{r}28 \\
\text { p lasma }\end{array}$ \\
\hline
\end{tabular}


TABLE VA

ANTIBACTERIAL ACTION OF MORHAL BLOOD MEASURED BY ITS ABILITY TO REDUCE THE NUMBER OF CULTURABLE STAPHYLOCOCCI COAGULASE POSITIVE DURING 6 HOUR IMCUBATION

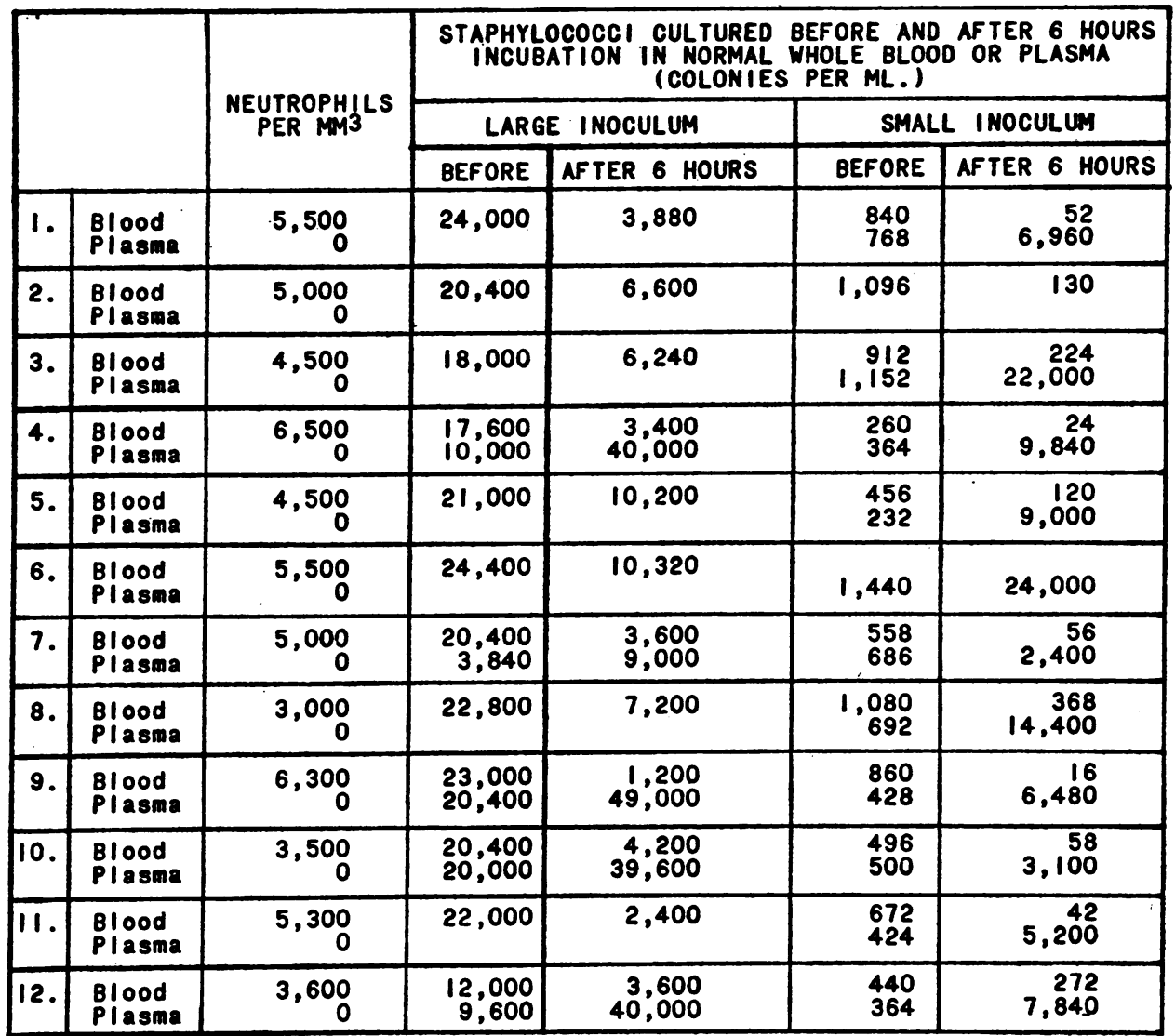

period as long as 6 hours was very destructive to the leukocytes. Before incubation, and immediately after removal from the incubator, the tubes were shaken to disperse the leukocytes and bacteria, and $0.5 \mathrm{ml}$. of the blood was removed each time and incorporated into agar pour plates and incubated at $37^{\circ} \mathrm{C}$. for 24 hours. The bacterial colonies were then counted. Normal whole blood was inoculated with staphylococci and treated in the same way. Results were not recorded if heavy growth failed to develop in cell-free plasma controls.

4. Phagocytic activity of normal leukocytes in leukemic plasma. The phagocytic system described in Section 2 was useful for demonstrating an antileukocyte factor in leukemic plasma. The procedure was identical except that normal leukocytes were resuspended in leukemic plasma instead of Ringer's solution. The leukemic and normal control plasmas had been collected on the dates indicated in Table VI and stored at $4^{\circ} \mathrm{C}$. until 5/19/53 and $5 / 21 / 53$ when they were removed for the experiments. In this way all plasmas were tested simultaneously against normal leukocytes obtained from a given sample of blood.

\section{RESULTS}

\section{Chronic granulocytic leukemia}

Pneumococci were phagocytosed by fewer mature leukemic neutrophils than by normal neutrophils in most experiments. Phagocytosis equal to that of the normal control was observed among leukocytes from only 2 of 14 leukemic patients (A. E. 3/6/53 and M. W.) at a time when both had experienced marked clinical and hematologic remission from successful therapy. In two other cases (T. B. 1/12/53 and E. S. 8/12/53) the per cent phagocytosis by mature neutrophils approached normal, but the average number of intracellular pneumococci per phagocytic cell was markedly lower than normal. Phagocytes from 7 of the 14 patients contained at one or more times an average number of intracellular pneumococci equal to or greater than the average observed in 
normal phagocytes serving as controls. Two of these patients were those who had undergone remission after treatment and whose leukocytes were all as active as normal. Only a fraction of the leukocytes from the other five patients were phagocytic, but the phagocytic cells were, on the average, as active as normal or more so. In addition to the two whose leukocyte function was normal during remission, three patients (M. L. $3 / 31 / 53$, E. J. 12/23/53, R. F. 4/2/53) and perhaps a fourth (T. B. 4/10/53) manifested improvement of leukocyte function after treatment with $\mathrm{x}$-ray or $\mathrm{P}_{\mathbf{3 2}}$. A sharp fall in phagocytic activity was observed in leukocytes from patient (M. R.) after the start of treatment with urethane.

Both band and segmented cells were regarded as mature neutrophils. Numerous reports have disclosed that there is no significant difference between the phagocytic activity of band forms and segmented forms from normal persons $(2-4,8)$. Phagocytosis by metamyelocytes was occasionally observed but rarely if ever occurred among myelocytes or younger cells in our preparations. Distinction between band and segmented forms was sometimes difficult when the cell contained numerous cocci. For this reason no attempt was made to compare quantitatively the relative phagocytic power of band cells and segmented cells. Table I discloses that in chronic granulocytic leukemia the per cent phagocytosis was usually much less than the per cent of segmented neutrophils in a given suspension. It is clear, therefore, that phagocytosis by segmented neutrophils was impaired in chronic granulocytic leukemia.

Samples of blood from each of the 12 patients whose mature neutrophils showed impaired phagocytosis of pneumococci reduced the number of culturable staphylococci in 6 hours as readily as normal blood. Bloods from a total of 19 of 20 patients lowered the total staphylococcal count as effectively, or more so, than normal blood. The one exception (E. H.) was a patient whose blood contained mostly band neutrophils. Although his blood did not lower the bacterial count, it prevented growth.

The observed impairment of phagocytosis by individual neutrophils in chronic granulocytic leukemia, as measured by the phagocytosis of pneumococci, was also demonstrated when the total neutrophil count of whole leukemic blood was reduced to normal. Thus, in bloods from seven patients, removal of the buffy coat not only reduced the neutrophil count to levels approaching normal, but also rendered the blood incapable of lowering significantly the count of staphylococci (Table V).

\section{Acute and subacute granulocytic leukemia}

The per cent phagocytosis by mature neutrophils was at least normal or nearly normal, in eight of nine patients (Table II). In five of these eight leukemic patients, the average number of pneumococci per phagocytic cell was normal or greater. Only in the suspension made from the cells of one patient (G. S.) were both the per cent phagocytosis and average number of intracellular bacteria reduced when compared to the normal control. $\mathrm{He}$ was the only patient of the nine whose total leukocyte count in the peripheral blood was greatly elevated when the test was performed. In three patients (P. C., F. S., and R. V.) there was a great increase in phagocytic activity over normal as judged both by per cent phagocytosis and number of bacteria per cell. Neutrophils from patient F. S. were so heavily packed with pneumococci that the bacteria could not be counted. All bloods from patients with acute or subacute granulocytic leukemia lowered the count of inoculated staphylococci as well as normal blood. The blood from two patients reduced the number of culturable staphylococci despite the presence of only 2,400 (patient E. T.) and 900 (patient F. S.) mature neutrophils per cu. $\mathrm{mm}$.

\section{Chronic lymphocytic leukemia (Table III)}

The per cent phagocytosis by mature neutrophils from five patients was essentially normal. The per cent phagocytosis by leukocytes from two patients (J. H. and J. M.) was reduced, but not by much. Phagocytes from five of the seven patients contained more intracellular pneumococci than normal, from one patient (J. M.) the same as normal, and only those from patient W. Y., less than normal. Two of the patients (J. P. and H. C.) whose leukocytes were more active than normal were receiving $\mathrm{x}$-ray therapy during the periods when the tests were made. Patient J. M., whose leukocyte function was slightly reduced, was also receiving $x$-ray therapy. 
Although the count of mature neutrophils was 4,000 per cu. $\mathrm{mm}$. or less in the blood of five of seven patients, normal or nearly normal reduction in numbers of inoculated staphylococci was observed in each case. The blood of patient A. R., containing only 3,600 mature neutrophils per cu. mm., reduced the number of culturable staphylococci by almost 90 per cent or more than that produced by normal blood. His leukocytes were also exceedingly active in the standardized phagocytic system against pneumococci.

\section{Acute and subacute monocytic and lymphocytic leukemias (Table IV)}

It was possible to test the neutrophils of only one patient (A. G.) for phagocytosis of pneumococci. These were more active than normal. Some of the promonocytes (per cent not determined) of patient $H$. T. showed tremendous phagocytic activity and engulfed so many pneumococci that the bacteria could not be counted in each cell.
These phagocytic promonocytes were apparently so active that they restrained the growth of inoculated staphylococci and even lowered the count on one occasion (4/17/53). Similar activity of monocytes or promonocytes may be evident in the case of W. S. whose blood reduced a small inoculum of staphylococci by nearly 50 per cent. The number of phagocytes in the bloods of the other three patients in this group were too low to restrain staphylococcal multiplication.

Phagocytic activity of normal leukocytes in leukemic plasmas (Table VI)

The plasmas obtained from patient M. L. (chronic granulocytic) and from patient F. S. (acute granulocytic) abolished the phagocytic activity of normal leukocytes obtained from two donors. These plasmas also damaged the neutrophils, producing severe lysis (plasma M. L.) or pyknosis (plasma F. S.). The plasmas of three other patients (A. G., subacute subleukemic

TABLE VI

PHAGOCYTIC ACTIVITY OF MORMAL NEUTROPHILES SUSPENDED IN LEUKEMIC PLASHAS

All plasmas were stored at $40 \mathrm{C}$. and later tested simultaneously with each sample of normal cells.

\begin{tabular}{|c|c|c|c|c|c|}
\hline & \multicolumn{2}{|c|}{ SOURCE OF LEUKEMIC PLASMA } & \multicolumn{2}{|c|}{$\begin{array}{c}\text { PER CENT OF NEUTROPHILES } \\
\text { SUSPENDED IN LEUKEMIC PLASMA } \\
\text { WHICH PHAGOCYTOSED OPSONIZED } \\
\text { TYPE } 2 \text { PNEUMOCOCCI }\end{array}$} & \multirow[t]{2}{*}{ APPEARANCE OF CELLS } \\
\hline CASE & DATE & TYPE OF LEUKEMIA & $\begin{array}{c}\text { NORMAL CELLS } \\
\text { J.F. }\end{array}$ & $\begin{array}{c}\text { NORMAL CELLS } \\
\text { A.B. }\end{array}$ & \\
\hline A.G. & $4 / 10 / 53$ & $\begin{array}{l}\text { Subacute subleukemlc } \\
\text { Iymphocytic }\end{array}$ & 72 & 50 & Lysis (of some cells) \\
\hline M.L. & $3 / 31 / 53$ & Chronic granulocytic & 0 & 0 & Lysis of all cells \\
\hline F.S. & $3 / 31 / 53$ & Acute granulocytic & 2 & 0 & Pyknosis of all cells \\
\hline H.T. & $4 / 29 / 53$ & Acute monocytic & 64 & 62 & Normal \\
\hline A.E. & $3 / 6 / 53$ & Chronic granulocytic & 50 & 65 & Normal \\
\hline E.L. & $3 / 6 / 53$ & $\begin{array}{c}\text { Subacute subleukemic } \\
\text { granulocytic }\end{array}$ & 68 & 86 & Normal \\
\hline J.P. & $4 / 24 / 53$ & Chronic Iymphocytic & 64 & 88 & Normal \\
\hline U.Y. & $2 / 24 / 53$ & Chronic Iymphocytic & 65 & 87 & Normal \\
\hline M.W. & $3 / 19 / 53$ & Chronic granulocytic & 75 & 70 & N̈ormal \\
\hline M.R. & $5 / 5 / 53$ & Chronic granulocytic & & 90 & Normal \\
\hline M.S. & $4 / 29 / 53$ & Chronic granulocytic & & 90 & Normal \\
\hline & Normal & Control. A & & 90 & \\
\hline & Normal & Control. B & & 96 & \\
\hline & Mormel & Control. C & 100 & & \\
\hline
\end{tabular}


TABLE VII

\section{INCIDENCE OF BACTERIAL IMFECTIONS IN LEUKEMIC PATIENTS}

\begin{tabular}{|c|c|c|}
\hline TYPE OF LEUKEMIA & TOTAL NUMBER OF CASES & $\begin{array}{l}\text { TOTAL NUMBER WITH } \\
\text { PROVEN BACTER I ALL } \\
\text { INFECTION }\end{array}$ \\
\hline Chronic Granulocytic & 24 & 2 \\
\hline Acute Granulocytic & 8 & 3 \\
\hline Chronic Lymphocytic & 10 & 0 \\
\hline Acute Lymphocytic & 2 & 0 \\
\hline Acute Monocytic & 3 & 0 \\
\hline
\end{tabular}

lymphocytic; H. T., acute monocytic; A. E., chronic granulocytic) also seemed to reduce phagocytosis of normal leukocytes, but not by much. The plasma of A. G. produced slight cytolysis.

\section{DISCUSSION}

There are at least two possible explanations for the decreased phagocytic activity of mature neutrophils in chronic granulocytic leukemia, observed in this study. One possible explanation is that there is an inherent defect in the leukemic cell. The other is that leukemic plasma contains a factor which is injurious to the neutrophil. Whatever the cause, the decreased phagocytic activity could not have been anticipated by morphologic study because the nuclear configuration and cytoplasmic structure of most of the mature leukemic neutrophils were normal. The existence of functional changes without morphologic abnormality in neutrophils has also been suggested by observations on leukocytes removed from patients with diabetes and anemia. Recently, Martin, McKinney, Green, and Becker (9) have reported that leukocytes from diabetics cannot oxidize glucose normally in vitro unless insulin is provided. In anemia, Berry and Spies (10) have found that neutrophils, instead of showing disturbed activity, possess greater phagocytic capacities than normal cells.

This state of reduced phagocytic capacity is not a universal feature of the leukemic process, however. In chronic lymphocytic leukemia, in acute granulocytic leukemia, and perhaps in acute lymphocytic leukemias, the individual function of the granulocytes was not usually disturbed. Because of the diminished total numbers of cells, however, the total antibacterial activity of whole blood in these conditions was sometimes less than that of blood from patients with chronic granulocytic leukemia and even less than normal.

It does not seem likely that the decreased activity of neutrophils in granulocytic leukemia was due to irradiation because leukocytes from patients who never received irradiation prior to the study displayed impaired phagocytic activity. Moreover, irradiation appears to enhance rather than depress phagocytic activity. Thus leukocytes from some patients with lymphocytic leukemia receiving Roentgen irradiation displayed greater phagocytosis than normal. In animals, irradiation has also produced greater phagocytosis than normal by neutrophils (11). There is little question that in several patients with granulocytic leukemia, radiation therapy actually produced an improvement in phagocytic activity. The effect of urethane appeared to differ from that of irradiation in the one patient studied because there was a decrease instead of increase in phagocytic activity.

Although the function of the individual cell is impaired in chronic granulocytic leukemia, the excess number of granulocytes raises the total antibacterial defense of the whole blood to normal. Since tissues receive their granulocytes from the blood, it is not surprising that the cellular morphology of the inflammatory reaction in infected tissues is normal in granulocytic leukemia. Jaffé (12) found that in these patients the cells comprising the inflammatory reaction had the appear- 
ance of normal neutrophils and they were present in normal numbers or greater.

Bacterial infections were not frequent among the patients in this report (Table VII). Only two patients with chronic granulocytic leukemia suffered from infection. These were both mild furuncles which were promptly localized. Three patients with acute granulocytic leukemia appeared to suffer bacterial infections. Two patients had a sore throat from which coagulase positive staphylococci were cultured. These bacteria are frequently present without producing infection and cannot be definitely regarded as the cause of the sore throats. A third patient experienced a generalized pustular eruption. All three cases recovered after receiving antibiotics. No bacterial infections were noted in 12 patients with lymphocytic leukemia. The relatively low incidence of severe infection in all patients studied may be correlated with observations on leukocyte function. In chronic granulocytic leukemia, an excess number of neutrophils offsets poor individual function. In lymphocytic leukemia, and in the acute leukemias, there appear to be enough normally active phagocytes for defense against bacterial infection even though the total numbers may be somewhat lower than normal. Thus, Jaffé (12) observed that patients with very low leukocyte counts could mobilize adequate numbers of neutrophils from isolated foci in the bone marrow to provide good cellular defense reactions to infection in the tissues. Other cells than granulocytes may also contribute significantly to cellular defense in leukemia. An example of this is provided by the patient with acute monocytic leukemia whose promonocytes were so actively phagocytic that whole blood containing them but no other phagocytes possessed total antibacterial properties equal to that of normal blood. The extreme susceptibility of certain patients with acute leukemia to bacterial infections appears to be a function of a marked decrease in total number of mature granulocytes rather than a decrease in function of individual cells.

The antiphagocytic and leukocyte-destroying properties of stored leukemic plasmas are recorded here as a preliminary observation of interest. The two plasmas most destructive for neutrophils were obtained from patients with granulocytic leukemia when their leukocyte counts were low. Yet the activity of their own leukocytes against staphylo- cocci was good in the fresh whole blood from which the stored plasmas were obtained. In one of these patients, however, the total leukocyte count had fallen from 220,000 to 16,500 just before the plasma was obtained. It remains to be determined if the factor in leukemic plasma which is toxic for leukocytes is related to the leukotoxic substance demonstrated by Doan (13), and what role, if any, it may have in the pathogenesis of leukemia.

\section{SUMMARY AND CONCLUSIONS}

Phagocytic activity of leukocytes in 45 cases of leukemia was studied by two methods: 1) Suspensions of leukemic and suspensions of normal leukocytes, containing approximately equal numbers of mature granulocytes were inoculated with opsonized type II pneumococcus and the phagocytic activity of leukemic cells was compared to that of normal granulocytes; 2) Heparinized leukemic blood was divided into two portions and buffy coat removed from one to lower the count of mature neutrophils to normal levels. Each portion was inoculated with pathogenic staphylococci and the number of culturable staphylococci were counted before and after 6 hours incubation.

Pneumococci were phagocytosed less actively by mature granulocytes from chronic granulocytic leukemia than by normal granulocytes. In lymphocytic leukemia, phagocytosis of pneumococci by granulocytes was usually normal. Treatment of patients by irradiation sometimes restored normal phagocytosis in granulocytic leukemia.

Similarly, in chronic granulocytic leukemia, when buffy coat was removed to leave a count of 5,000 to 10,000 mature granulocytes per $\mathrm{ml}$. of blood, the number of culturable staphylococci was often not significantly lowered. Yet normal bloods averaging 5,000 mature granulocytes markedly reduced the numbers of staphylococci. If buffy coat was not removed, blood from chronic granulocytic leukemia also reduced markedly the number of staphylococci.

In chronic granulocytic leukemia, phagocytosis by individual granulocytes was usually impaired but overproduction of granulocytes raised the total defense of the blood to normal. In chronic lymphocytic, and certain acute leukemias, individual function of mature granulocytes is usually undisturbed, but decrease in total numbers sometimes weakens antibacterial defense. 


\section{REFERENCES}

1. Hertzog, A. J., The phagocytic activity of human leukocytes with special reference to their type and maturity. Am. J. Path., 1938, 14, 595.

2. Strumia, M., and Boerner, F., Phagocytic activity of circulating cells in the various types of leukemia. Am. J. Path., 1937, 13, 335.

3. Huddleson, I. F., and Munger, M., Phagocytic activity of bone-marrow cells. Proc. Soc. Exper. Biol. \& Med., 1936, 35, 27.

4. Jersild, M., Phagocytic activities of various types of leucocytes. Acta med. Scandinav., 1948, Supplement 213, 238.

5. Hirschberg, N., Phagocytic activity in leukemia. Am. J. Med. Sc., 1939, 197, 706.

6. Condensation of the first two reports of the Committee for Clarification of the Nomenclature of Cells and Diseases of the Blood and Blood-forming Organs. Blood, 1949, 4, 89.

7. Braude, A. I., and Feltes, J., Studies in the destruction of staphylococci by human leukocytes: effect of clumping of intracellular and extracellular bacteria on the results obtained with the agar-plate method. J. Lab. \& Clin. Med., 1953, 42, 289.

8. Ponder, E., and Flinn, Z. M., Studies on the Arneth Count. I. The relation between phagocytosis and nuclear configuration. Quart. J. Exper. Physiol., 1927, 16, 207.

9. Martin, S. P., McKinney, G. R., Green, R., and Becker, C., The influence of glucose, fructose, and insulin on the metabolism of leukocytes of healthy and diabetic subjects. J. Clin. Invest., 1953, 32, 1171.

10. Berry, L. J., and Spies, T. D., Phagocytosis. Medicine, 1949, 28, 239.

11. Esplin, D. W., Marcus, S., and Donaldson, D. M., Effects of $x$-irradiation and adrenalectomy on phagocytic activity. J. Immunol., 1953, 70, 454.

12. Jaffé, R. H., Morphology of the inflammatory defense reactions in leukemia. Arch. Path., 1932, 14, 177.

13. Doan, C. A., The recognition of a biologic differentiation in the white blood cells. J.A.M.A., 1926, 86, 1593. 